Article

\title{
Educated Millennials and Credence Attributes of Food Products with Genetically Modified Organisms: Knowledge, Trust and Social Media
}

\author{
Carlo Russo ${ }^{1, *}$, Mariarosaria Simeone ${ }^{2}$ and Maria Angela Perito ${ }^{3,4}$ \\ 1 Department of Economics and Law, University of Cassino and Lazio Meridionale, 03043 Cassino, Italy \\ 2 Department of Law, Economics, Management and Quantitative Methods (DEMM) University of Sannio, \\ 82100 Benevento, Italy; msimeone@unisannio.it \\ 3 Faculty of Bioscience and Technology for Food, Agriculture and Environment, University of Teramo, \\ 64100 Teramo, Italy; maperito@unite.it \\ 4 INRAE, UR ALISS, Université Paris-Saclay, 94205 Ivry-sur-Seine, France \\ * Correspondence: carlo.russo@unicas.it
}

Received: 28 August 2020; Accepted: 12 October 2020; Published: 15 October 2020

\begin{abstract}
In this paper, we investigated educated millennials' evaluation of credence attributes in food products containing genetically modified organisms (GMO products). Our goal is to assess whether beliefs about GMO products are determined by scientific knowledge alone or if they are affected by other factors such as trust in information providers and use of social media. The focus on millennials is motivated by the increasing relevance of this social group in the public debate and by their extensive use of social media. We surveyed a sample of 215 Italian college students, confronting them with questions about safety, environmental impact and ethical issues in GMO product consumption. Using an ordered probit regression model, we found that educated millennials build their beliefs using a mix of scientific knowledge and trust in information providers. The role of the two drivers depended on the issue considered. Scientific knowledge drove beliefs in health claims, while trust in information providers was a driving factor in almost all claims. After controlling for trust effects, we did not find evidence of impact of confidence in the reliability of traditional and social media on beliefs. This result contradicts previous literature.
\end{abstract}

Keywords: genetically modified products; educated millennials; social media; trust

\section{Introduction}

In this paper, we investigate how educated millennials build their beliefs about credence attributes of food products containing genetically modified organisms (GMO products). Our choice of focusing on this specific social group is motivated by the increasing role of millennials in shaping food demand for GMO products and by their unique characteristics, such as the extensive use of social media $[1,2]$. Yet, existing literature provides conflicting results regarding their beliefs (e.g., [3-6]) and their attitude towards GMO products is still an open question [7].

Our study hypothesis is that educated millennials' beliefs about GMO product credence attributes are not determined by scientific knowledge alone. Because the scientific debate regarding GMO products is complex, consumers may be unable to verify information and their evaluation might be based on their trust in the information providers (such as environmental associations, farmers, etc.) and the media [8-10]. The study question is of particular importance because consumption decisions based on incorrect information provided by interested parties might result in a market failure [11].

Unlike previous studies, we do not focus on willingness to buy or pay for GMO products directly (e.g., [12]). Instead, we model a set of beliefs regarding ethics, health and environmental safety, under 
the assumption that, ultimately, consumers' purchasing choice depends on such beliefs. Our goal is to assess whether beliefs are influenced by trust in information providers or by the use of social media. The advantage of this approach is twofold. Firstly, we can assess if the influence of social media or information providers depends on the specific subject of the beliefs. Willingness to pay is a concise indicator of consumer's beliefs and information and it does not allow us to address beliefs about specific issues. Secondly, in this way we attenuate the hypothetical bias that is typical of questionnaire-based measurement of willingness to pay [13].

Our paper contributes to a long-standing debate in the academia and in the entire society about consumer acceptance of GMO products [14]. Although a complete literature review on the topic goes beyond the scope of this paper, in this section we provide a general overview of the contributions that motivated our research and are helpful to frame our research question (for detailed reviews, see $[15,16])$.

Despite the fact that scientific research conducted on GMO products found them no more hazardous than conventional alternatives [17,18] and the production of extensive public regulation [19-21], consumer wariness about GMO products persists in many countries [22,23]. The attitude persisted even when the so-called "second generation" of value-oriented GMO products was released and consumers could benefit from improved nutritional properties of biotech food [24].

GMO products are perceived by consumers across many countries as a major threat to biodiversity, the environment and human health [25-28]. Concerns are related both to specific risk and benefit perception [15,29]. They also relate to general moral issues about manipulating life and the ecosystem [30,31]. Noticeably, ethical concerns persist even in front of the possible role of GMO products in reducing world hunger [32]. Given this literature, we focused our investigation on GMO product credence attributes on health, environmental impact and ethical/moral issues as the key factors driving consumer acceptance.

Perfectly rational consumers are able to evaluate product attributes perfectly and then decide on their purchase based on a consistent system of preferences [33]. Existing literature suggests that such an ideal model can be hardly applied to GMO product consumption. According to Li and Basu [34], most consumers are unable to fully understand the technical information about GMO products. Kim and Boyd [6] confirmed this result in their investigation of Japanese consumers. Zhang et al. [35] pointed out that misinformation might be a consequence of the difficulty of the scientific community in explaining GMO products concisely to the lay public. Instead, immediate (although imprecise) metaphors are highly effective in evoking emotions regarding GMO products, when consumers have incomplete knowledge [36,37].

Bardin et al. [38] found that consumer ability to process technical information regarding GMO products is a key determinant of acceptance. McComas et al. [39] ran a study on GMO product acceptance by US consumers and concluded that consumers who are more informed are more likely to support the use of biotechnology in food production than those who are less informed. Similar results are reported in Mielby et al. [40] about Danish consumers. Kim et al. [41] interviewed a sample of Korean respondents and concluded that education programs were needed in order to help consumers to have a clear assessment of GMO products. Park and Lee [42] found that the framing of GMO product labels played an important role in shaping perceptions of a sample of US students.

Economic literature investigated consumer choice for products with "controversial characteristics", i.e., goods with credence attributes that consumers are not able to evaluate directly such as GMO products [43,44]. Marette and Roosen [45] modelled the choice of a consumer whose awareness of a specific product characteristic (or externality) is limited and derived the optimal policy. A similar approach is in a theoretical paper by Russo and Tufi [11], where the authors investigated the impact of trust in information providers on the equilibrium in a market when firms compete in information and price.

The role of trust in information providers was investigated and confirmed in empirical studies as well [46-48]. A study on risk perception found that consumers trust more public specialists (university 
scientist, environmental group and consumer organizations) than governments, retailers and industry as sources of information on GMO products [49]. A survey by Lang [50] found that consumers trust university scientists more than farmers, environmental organizations, government agencies, retailers and food manufacturers.

Other contributions focused on the means by which consumers collect information. Media sources are often used as a central channel of communication to transfer information from the providers to consumers [51]. According to Wunderlich and Gatto [8], consumers trust the internet and mass media for information about GMO products, even if this information can be imprecise or ambiguous. As a consequence, purchase decisions may be affected by the level of confidence in each type of media [9]. De Steur et al. [52] found an association between the type of media used by a sample of Chinese consumers to collect information and their attitude toward genetically modified rice.

This brief review of the literature suggests that, thirty years after the biotech revolution, GMO products are still controversial in the eye of public opinion. Educated millennials' beliefs will become increasingly important to determine acceptance of GMO products and yet they are still not fully understood by the economic literature. This result motivates our empirical investigation.

Our research contributes to the understanding of educated millennials' beliefs regarding GMO products in two ways. Firstly, we investigate beliefs regarding several issues, without limiting our analysis to safety. We include in the analysis environmental and ethical concerns that are of increasing importance for food consumers in general and millennials in particular. This approach allows us to assess that millennials build their beliefs differently, depending on the issue that is being considered. Secondly, we provide a joint estimate of the effects of scientific knowledge, trust in information providers and social media on the educated millennials' beliefs. By including regression measures of these three drivers, we are able to control for possible bias in the estimates. In fact, after controlling for trust, we find that social media do not affect beliefs, a result that contradicts previous studies [8-10].

The paper is organized as follows: In Section 2 we present the sample data and the empirical strategy. In Section 3 we report the variable measurement and the result of the ordered probit regression. Section 4 reports the discussion of the results and Section 5 summarizes the conclusions, limitations of the study and future research.

\section{Materials and Methods}

In order to address the study question, we surveyed 215 Italian college students from three mid-size universities in central Italy. Respondents were contacted in person at the University and invited to fill in a self-administered online questionnaire. The questionnaire is composed of three parts: (i) background information, including demographics (gender, age, shopping habits) and education (type of degree and programs); (ii) respondents' evaluation of a set of statements (regarding safety, environmental impact and ethical issues of GM products); (iii) respondents' assessments of their trust in a set of information providers, confidence in the reliability of a set of social media. The English translation of the questionnaire is attached in the Appendix A.

Table 1 reports the descriptive statistics of demographic and education variables. We segmented the sample based on the field of study, identifying students who were enrolled in Science, Technology, Engineering and Mathematics programs (STEM). We also distinguish between undergraduate and master students.

\section{Empirical Strategy and Hypotheses}

We designed our empirical analysis building on the theoretical foundation in [11]. Following this approach, we consider an individual consumer $i$ evaluating a claim regarding a credence attribute of a GMO product. In a perfect information model, the consumer knows whether the claim is true or false with a probability of one. Instead, under bounded rationality, the consumer must assess the 
truthfulness of the statement with the available information, resources and time. In this approach, consumer $i$ maximizes the following expected utility function:

$$
E\left(U_{i}\right)=\hat{s}_{i} \cdot U_{i}(x \mid c=1)+\left(1-\hat{s}_{i}\right) \cdot U_{i}(x \mid c=0)
$$

where $x$ is a Lancasterian attribute vector [53], $c$ is a binary variable that is equal to 1 if the claim is true and $\hat{s}_{i}$ is $i^{\prime}$ s subjective estimate of the probability that the claim is true summarizing the respondent's beliefs about the claim.

Table 1. Sample descriptive statistics.

\begin{tabular}{cccccc}
\hline & Count & $\begin{array}{c}\text { Age } \\
\text { (Average) }\end{array}$ & \multicolumn{2}{c}{$\begin{array}{c}\text { Gender } \\
\text { (Proportion) }\end{array}$} \\
\hline Program & Degree & No. & Years & F & M \\
\hline Not STEM & Undergrad. & 58 & 21 & 0.59 & 0.41 \\
& Master & 22 & 25 & 0.82 & 0.18 \\
\hline STEM & Undergrad. & 126 & 21 & 0.71 & 0.29 \\
& Master & 9 & 24 & 0.78 & 0.22 \\
\hline Total & & 215 & 21 & 0.69 & 0.31 \\
\hline
\end{tabular}

Equation (1) describes the role of beliefs in determining consumption when the characteristics of the goods are controversial. The value of expected utility, and ultimately the consumption decision, depends on the subjective estimate $\hat{s}_{i}$. In our empirical investigation, we are interested in finding the drivers of $\hat{s}_{i}$.

Our hypothesis is that the subjective evaluation by consumer $i$ of claim $k$ is a function

$$
\hat{s}_{i, k}=f\left(I, \boldsymbol{\theta}_{i}, \boldsymbol{\mu}_{i}, \zeta_{i}, \boldsymbol{\rho}_{i}, \varepsilon_{i, k}, \boldsymbol{\beta}_{k}\right)
$$

of the set of available information $(I)$, which is assumed to be the same for all consumers, a vector defining consumer $i$ 's level of trust in all information providers $\left(\boldsymbol{\theta}_{i}\right)$, a vector measuring $i$ 's confidence in all media $\left(\mu_{i}\right), i^{\prime}$ s individual ability to process information $\left(\zeta_{i}\right)$, a vector of individual characteristics $\boldsymbol{\rho}_{i}$, and an error term $\varepsilon_{i, k}$ capturing unobserved heterogeneity about $i$ and claim-specific effects. $\boldsymbol{\beta}_{k}$ is a vector of claim-specific parameters to be estimated.

Our empirical strategy is based on a three-step approach. In step 1, we measure the variables of interest, namely the subjective estimates of the truthfulness of the claim $\left(\hat{s}_{i, k}\right)$, the respondent's level of scientific knowledge $\left(\zeta_{i}\right)$, the trust in a list of information providers $\left(\boldsymbol{\theta}_{i}\right)$, the confidence in the reliability of a list of media $\left(\mu_{i}\right)$. The results of the measure are reported in Section 3.1, Section 3.2, Section 3.3.

In the second step, we regress our measure of $\hat{s}_{i, k}$ on the explanatory variables according to the specification in Equation (2) using an ordered probit model. In this way, we obtain estimates of the population parameters $\beta_{k}$. The results of the regressions are reported in Section 3.4.

In step 3 we test specific hypotheses on the value of $\boldsymbol{\beta}_{k}$. Let $\boldsymbol{\beta}_{k}^{\theta}, \boldsymbol{\beta}_{k}^{\mu}, \boldsymbol{\beta}_{k}^{\zeta}$ be the subsets of population parameters of the three drivers of interest: trust in information providers, confidence in media, and scientific knowledge, respectively. If a $\chi^{2}$ test fails to reject the null hypothesis that a group of population parameters is equal to zero, we conclude that there is no statistical evidence that the driver affects beliefs. Furthermore, observing the outcomes of the tests for each regression (claim) we can assess whether the drivers are the same regardless of the claim or if they are claim-specific. The results of the tests are reported in Section 3.4. 


\section{Results}

In this section, we report the results of the empirical analysis. First, we illustrate the measurement strategy for the dependent and explanatory variables, then we present the results of the regressions and hypothesis testing.

\subsection{Measuring Subjective Assessment of Truthfulness}

We measure the variable $\hat{s}_{i, k}$ asking respondents to agree or disagree with a set of 13 claims using a five-point Likert scale (with 1 being "totally disagree" and 5 being "totally agree"). The use of Likert scales turns the unobservable variable $\hat{s}_{i, k}$ into a discrete observable $y_{k, i}$, with

$$
y_{k, i}= \begin{cases}5 \text { if } & \tau_{k, 4} \leq \hat{s}_{i, k} \leq 1 \\ 4 \text { if } & \tau_{k, 3} \leq \hat{s}_{i, k}<\tau_{k, 4} \\ 3 \text { if } & \tau_{k, 2} \leq \hat{s}_{i, k}<\tau_{k, 3} \\ 2 \text { if } & \tau_{k, 1} \leq \hat{s}_{i, k}<\tau_{k, 2} \\ 1 \text { if } & 0 \leq \hat{s}_{i, k}<\tau_{k, 1}\end{cases}
$$

where $\tau_{k, 1} \ldots \tau_{k, 4}$ are probability threshold values, according to standard ordered-response models [54].

The questions were presented in the form of statements related to GMO product credence attributes and focused on three areas: safety, environmental and ethical issues. Figure 1 reports the item in the questionnaire and the distribution of the respondents' evaluations.

\subsection{Measuring Trust in Information Providers and Confidence in Media}

Trust is measured with questions asking for a subjective evaluation of the trustworthiness of a set of providers of information concerning GMO products. Respondents are asked to rank them on a 5-point scale from 1 (Totally untrustworthy) to 5 (Totally trustworthy). The list of information providers includes:

- $\quad$ Farmers

- Corporations

- Environmental associations

- Consumer associations

- Physicians

- Researchers

- Friends/Relatives

- Other information providers

The set of variables TIP is defined as the respondents' statements regarding the trustworthiness of information providers and it is our measure of the vector $\theta_{i}$.

We ask respondents to rate their confidence in the reliability of a broad set of media. Electronic media includes information websites (such as news website, official sites, etc.), blogs, social media (such as Facebook, Instagram), P2P media (such as TripAdvisor or similar platforms) or e-buzzword (such as WhatsApp). We consider Newspapers/Magazines, Radio and TV as traditional media. A residual category (other media) was included in the questionnaire. Confidence in media is assessed asking to rank each media on a 1 (Totally unreliable) to 5 (Totally reliable) scale. The set of variables CIM reporting respondents' statements regarding the confidence in media reliability measures the vector $\mu_{i}$. Figure 2 reports the results of the survey. 

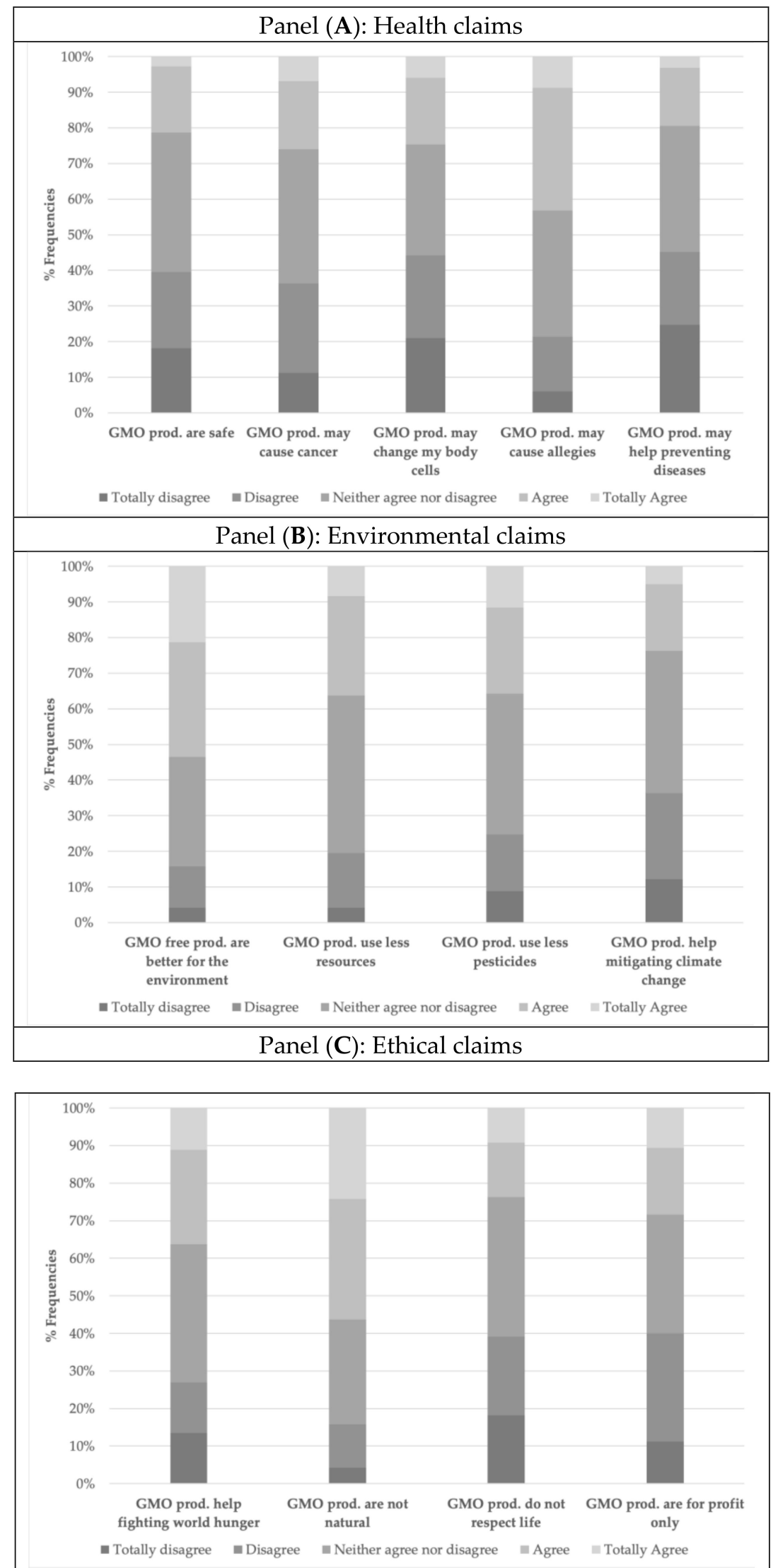

Figure 1. Evaluation of credence attributes of food products with genetically modified organisms. Panel A reports the evaluation of health claims, Panel B reports the evaluation of environmental claims, Panel $\mathrm{C}$ reports the evaluation of ethical claims. 


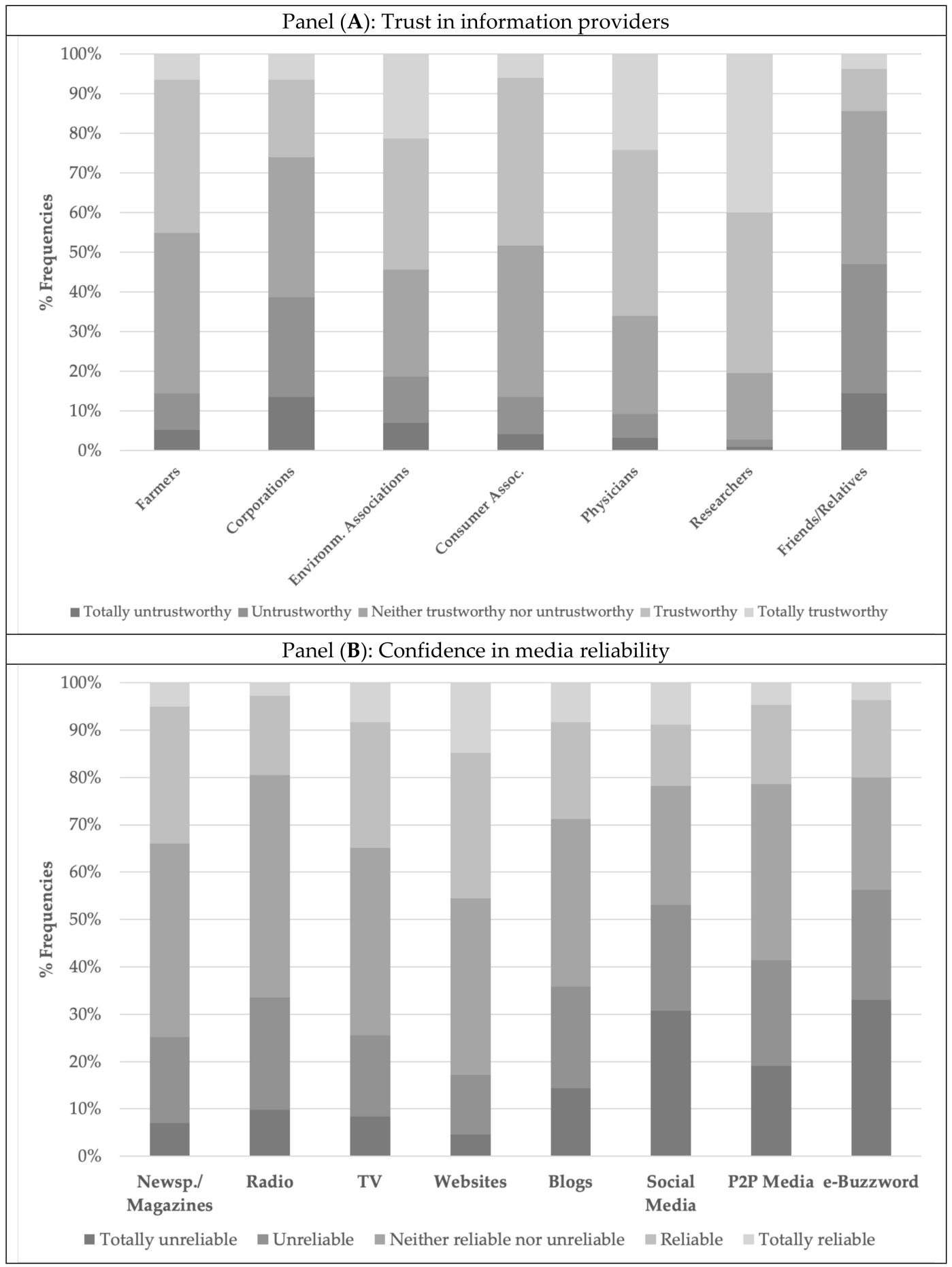

Figure 2. Evaluation of trust in information providers (Panel A) and confidence in media reliability (Panel B).

In order to consider differences in subjective evaluations, individual TIP and CM variables are expressed as deviations from the mean evaluation of each individual. The transformation is necessary to avoid that results are driven by general attitudes toward information providers or media of respondents (such as trusting everyone or no one). Let $T I P_{i, j}$ be the Likert score measuring respondent $i$ 's trust in the $j$ th information provider (with $j=1, \ldots, 8$ ) and $C M_{i, h}$ be the score measuring $i$ 's confidence in the $h^{\text {th }}$ media (with $h=1, \ldots, 8$ ). We define respondent $i$ 's mean level of trust in information providers as $A T I P_{i}=\frac{1}{8} \sum_{j=1}^{8} T I P_{i, j}$ and the average level of confidence in media as $A C M_{i}=\frac{1}{9} \sum_{l=1}^{9} C M_{i, l}$. In order to 
avoid perfect collinearity in the relative scores we collected respondent evaluations regarding additional residual categories ("other expert" for TIP and "other media" for CM). The residual categories were dropped from the regression but they are used to compute ATIP and ACM. In this way $\Sigma$ tip $_{k} \neq 0$ and $\Sigma \mathrm{CM}_{\mathrm{h}} \neq 0$ and we avoided perfect collinearity in the model.

The two variables control for differences in the average levels of trust in information providers and confidence in media across consumers. Figure 3 reports the distribution of the average variables $\mathrm{ACM}$ and ATIP. The relative trust in information provider $k$ was defined as $t i p_{i, j}=T I P_{i, j}-A T I P_{i}$ and the relative confidence in media as $c m_{i, h}=C M_{i, h}-A C M_{i}$.

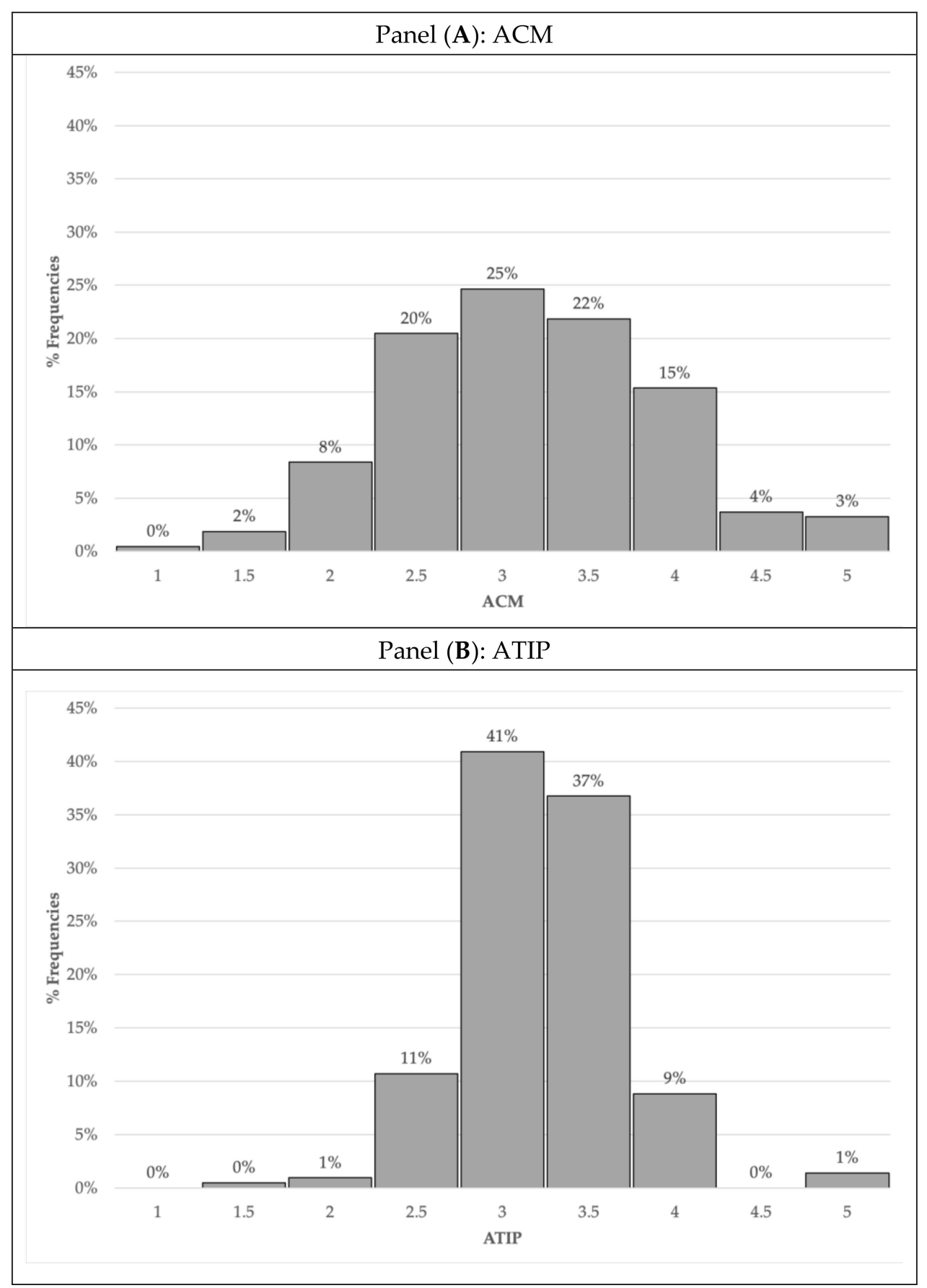

Figure 3. Distribution of ACM (Panel A) and ATIP (Panel B) variables. 


\subsection{Measuring Respondents' Ability to Process Scientific Information}

The focus on college-educated millennials allows us to observe scientific knowledge directly. We measured the ability to process scientific information $\zeta_{i}$ with the type of program respondents are enrolled in. We assume that students in STEM (science, technology, engineering and mathematics) programs have more advanced capabilities to process scientific information than those in non-STEM programs. In this way, we can observe the effect of scientific knowledge without the need to provide specific information to the respondents during the survey, unlike previous literature [39].

Noticeably, the choice of education program may reflect respondents' meta-attitudes toward "science", with STEM students having a "more positive" attitude than others toward GMO products [55]. Such meta-attitudes may affect the respondents' assessment of the claim, leading STEM students to agree with positive claims about GMO products regardless of the available scientific information. In order to control for a possible meta-attitude effect, we confronted respondents with mixed claims. Ethical claims have no clear answer from a scientific standpoint. A statistically significant impact of the study program on the assessment of such variables may be considered as evidence of a meta-attitude effect.

In order to improve the measurement of respondents' ability, we collected information on the type of program (undergraduate or master's; PhD students were excluded from the sample). In the regression we used two binary variables and an interaction term. The variable $S T E M_{i}$ is equal to 1 if respondent $i$ is enrolled in a STEM program and 0 otherwise, GRAD is equal to 1 if the respondent is a master's student and 0 if undergraduate. The interaction term is obtained by multiplying the two binary variables. The three variables formed the vector CPI measuring the variable $\zeta_{i}$.

Finally, we use a gender variable to summarize the vector $\rho_{i}$ of personal characteristic, due to data limitation. The variable $G E N_{i}$ is equal to 1 if the respondent is male and 0 otherwise.

\subsection{The Regression}

Our objective is to establish whether there is a systematic effect of CPI, tip and $\mathrm{cm}$ variables on the respondents' evaluations of the credence attributes of GMO products. To this end we run a set of ordered probit regressions of the respondents' evaluations regarding the issues of safety, environmental impact and ethics according to the specification in Equation (2).

Using a typical ordered probit model, we assumed that the observed dependent variable (respondents' evaluations on a Likert scale of the $k^{\text {th }}$ issues related to credence attributes) approximated the unobserved $\hat{s}_{i, k}$ variable and that the function $f$ in Equation (2) is linear, with:

$$
\begin{gathered}
\hat{s}=\sum_{g=0}^{1} \sum_{h=0}^{1} \beta_{g, h}^{\zeta} S_{T E M^{g} G R A D^{h}} \\
+\sum_{j} \beta_{j}^{\theta} t_{j}+\beta_{0}^{\theta} \mathrm{ATIP}+\sum_{l} \beta_{l}^{\mu} c m_{l}+\beta_{0}^{\mu} \mathrm{ACM}+\beta^{\rho} G E N+\varepsilon
\end{gathered}
$$

The $\beta^{\prime}$ s are regression parameters to be estimated and $\varepsilon$ is a heteroskedastic error term (robust standard errors were used in the regressions). For ease of notation we drop the $i$ and $k$ subscripts in Equation (4) and in the remainder of the paper. 
Based on the model, we tested three effects on the evaluation of GMO product credence attributes. The trust effect assesses the influence of trust in the information providers. The null hypothesis is that all the coefficients of the $t i p_{j}$ variables are jointly not statistically different from zero. The media effect concerns the joint statistical significance of the coefficients of $\mathrm{cm}_{l}$ variables. If we fail to reject the null hypothesis, we concluded that the confidence in reliability of social or traditional media does not affect the evaluation. Finally, we investigated an education effect, testing the joint significance of the $C P I$ variables. If the variable coefficients are statistically different from zero, we conclude that college education (and therefore scientific education) affects the evaluation of credence attributes.

Table 2 reports the results of the model estimation for the questions related to GMO products safety and health. The estimation identifies at least one statistically significant ( $95 \%$ confidence) effect for all items except the statement "GMO products may cause allergies".

We detected a trust effect in the evaluation of four items. The influential information providers are Environmental Associations (4 items), Corporations ( 3 items), Researchers ( 2 items) and Farmers ( 2 items). Against expectations, trust in physicians does not affect the evaluation of safety issues.

The signs of the coefficients of the tip variable related to Environmental Associations are opposite to those of the variable related to Corporations. Because the two information providers often release conflicting statements, the result is consistent with a statistically significant trust effect.

Our data do not support any media effect. The $\chi^{2}$ test failed to reject the null hypothesis that all coefficients are jointly equal to zero.

The education effect was detected in three items (safety, possible association with cancer, possible role in preventing diseases). There is no final evidence of a meta-attitude effect. The coefficient of the STEM variable in the regression of the allergy claim is not statistically different from zero and is opposite to the sign of the interaction variable. The data do not show an unconditional, consistent and statistically significant positive attitude of STEM students toward GMO products.

We find empirical evidence of a trust effect in the evaluation of issues related to GMO product environmental impact (Table 3). Environmental associations are the main opinion leaders in these topics. When considering environmental issues, data do not support a statistically significant effect of trust in researchers at $95 \%$ confidence level. Note that researchers are considered among the most trustworthy sources (Figure 2). Yet, such trust is not considered when evaluating environmental issues. This result is consistent with the limited evidence of education effect (that we find in one issue only). There is no evidence of a meta-attitude effect. No evidence of media effect is found.

Table 4 reports the regression results for the respondents' evaluations of GMO product ethical issues. The analysis confirms the importance of the trust effect, that is found in all issues. Education effect is supported by data only for the evaluation of GMO product role in fighting world hunger $(95 \%$ confidence level). We do not find evidence of media effects. Noticeably, the coefficient of the STEM variable in the regression on the claim "GMO products do not respect life" is negative and statistically significant at $95 \%$ confidence level. 
Table 2. Results of the ordered probit regression of respondents' evaluation of issues related to GMO product health and safety attributes (the dependent variables are measured on a 1 (totally disagree) to 5 (totally disagree) Likert scale. ( $p$-values marked in bold indicate coefficients that are statistically different from zero at $95 \%$ confidence level)

\begin{tabular}{|c|c|c|c|c|c|c|c|c|c|c|c|c|c|c|c|c|}
\hline & \multirow[b]{2}{*}{ Variable } & \multicolumn{3}{|c|}{$\begin{array}{l}\text { GMO Products } \\
\text { Are Safe }\end{array}$} & \multicolumn{3}{|c|}{$\begin{array}{c}\text { GMO Products } \\
\text { May Cause Cancer }\end{array}$} & \multicolumn{3}{|c|}{$\begin{array}{l}\text { GMO Products May } \\
\text { Change My Body Cells }\end{array}$} & \multicolumn{3}{|c|}{$\begin{array}{l}\text { GMO Products May } \\
\text { Cause Allergies }\end{array}$} & \multicolumn{3}{|c|}{$\begin{array}{l}\text { GMO Prod. May Help } \\
\text { Preventing Diseases }\end{array}$} \\
\hline & & Coef. & S. Err. & $p$-Val. & Coef. & S. Err. & $p$-Val. & Coef. & S. Err. & $p$-Val. & Coef. & S. Err. & $p$-Val. & Coef. & S. Err. & $p$-Val. \\
\hline & GEN & 0.385 & 0.169 & 0.022 & -0.190 & 0.159 & 0.232 & -0.089 & 0.172 & 0.606 & -0.035 & 0.159 & 0.824 & -0.076 & 0.169 & 0.654 \\
\hline & GRAD & -0.251 & 0.285 & 0.379 & 0.645 & 0.366 & 0.078 & -0.258 & 0.281 & 0.358 & -0.390 & 0.259 & 0.132 & -0.270 & 0.297 & 0.363 \\
\hline & STEM & 0.704 & 0.205 & 0.001 & -0.446 & 0.195 & 0.022 & -0.315 & 0.188 & 0.094 & -0.222 & 0.191 & 0.244 & 0.372 & 0.182 & 0.042 \\
\hline & STEM*GRAD & 0.548 & 0.525 & 0.296 & -0.503 & 0.435 & 0.247 & -0.180 & 0.505 & 0.721 & 0.474 & 0.527 & 0.369 & 0.527 & 0.541 & 0.330 \\
\hline \multirow[t]{8}{*}{$t^{t i p_{j}}$ variables } & Farmers & 0.019 & 0.109 & 0.862 & -0.072 & 0.103 & 0.487 & 0.209 & 0.111 & 0.060 & -0.085 & 0.103 & 0.409 & -0.224 & 0.106 & 0.034 \\
\hline & Corporations & 0.345 & 0.095 & 0.000 & -0.291 & 0.101 & 0.004 & -0.361 & 0.087 & 0.000 & -0.144 & 0.095 & 0.130 & 0.126 & 0.090 & 0.163 \\
\hline & Environ. Assoc. & -0.246 & 0.088 & 0.005 & 0.248 & 0.092 & 0.007 & 0.240 & 0.100 & 0.016 & 0.028 & 0.088 & 0.753 & -0.257 & 0.081 & 0.001 \\
\hline & Cons. Assoc. & -0.058 & 0.116 & 0.617 & 0.066 & 0.115 & 0.563 & -0.179 & 0.119 & 0.132 & 0.168 & 0.114 & 0.139 & -0.115 & 0.109 & 0.291 \\
\hline & Physicians & -0.062 & 0.118 & 0.600 & 0.001 & 0.107 & 0.993 & -0.029 & 0.099 & 0.772 & -0.097 & 0.115 & 0.398 & -0.093 & 0.102 & 0.365 \\
\hline & Researchers & 0.530 & 0.126 & 0.000 & -0.364 & 0.104 & 0.000 & -0.221 & 0.113 & 0.052 & -0.054 & 0.109 & 0.619 & 0.183 & 0.109 & 0.092 \\
\hline & Friends/Relativ. & -0.065 & 0.098 & 0.506 & 0.150 & 0.123 & 0.221 & 0.142 & 0.113 & 0.210 & 0.080 & 0.118 & 0.495 & 0.086 & 0.104 & 0.413 \\
\hline & ATIP & 0.711 & 0.235 & 0.002 & -0.459 & 0.193 & 0.017 & -0.156 & 0.253 & 0.537 & 0.229 & 0.235 & 0.331 & 0.527 & 0.226 & 0.020 \\
\hline \multirow[t]{10}{*}{$\mathrm{cm}_{l}$ variables } & Newsp./Mag. & -0.144 & 0.157 & 0.359 & 0.188 & 0.164 & 0.232 & -0.028 & 0.193 & 0.887 & 0.351 & 0.159 & 0.027 & -0.303 & 0.155 & 0.051 \\
\hline & Radio & 0.086 & 0.146 & 0.553 & 0.079 & 0.149 & 0.597 & 0.328 & 0.162 & 0.043 & -0.051 & 0.163 & 0.757 & 0.103 & 0.157 & 0.509 \\
\hline & TV & 0.015 & 0.158 & 0.926 & -0.149 & 0.139 & 0.284 & -0.091 & 0.150 & 0.544 & 0.138 & 0.164 & 0.400 & -0.138 & 0.149 & 0.352 \\
\hline & Websites & 0.177 & 0.135 & 0.191 & -0.032 & 0.142 & 0.822 & -0.091 & 0.178 & 0.611 & 0.063 & 0.154 & 0.682 & -0.051 & 0.152 & 0.739 \\
\hline & Blogs & 0.031 & 0.134 & 0.815 & -0.049 & 0.148 & 0.743 & 0.097 & 0.149 & 0.514 & 0.287 & 0.147 & 0.051 & -0.331 & 0.162 & 0.042 \\
\hline & Social Media & 0.063 & 0.124 & 0.610 & 0.087 & 0.109 & 0.423 & 0.048 & 0.119 & 0.685 & 0.109 & 0.139 & 0.432 & 0.044 & 0.130 & 0.734 \\
\hline & P2P Media & -0.137 & 0.137 & 0.319 & -0.104 & 0.148 & 0.482 & 0.133 & 0.142 & 0.350 & 0.157 & 0.170 & 0.358 & -0.176 & 0.160 & 0.272 \\
\hline & e-Buzzword & 0.058 & 0.122 & 0.634 & -0.076 & 0.102 & 0.453 & 0.053 & 0.107 & 0.622 & -0.036 & 0.130 & 0.782 & -0.115 & 0.121 & 0.341 \\
\hline & $\mathrm{ACM}$ & -0.073 & 0.158 & 0.641 & 0.349 & 0.143 & 0.015 & 0.125 & 0.154 & 0.415 & 0.004 & 0.148 & 0.981 & -0.060 & 0.142 & 0.674 \\
\hline & constant & -1.651 & 0.788 & 0.036 & 5.469 & 1.490 & 0.000 & 1.759 & 0.743 & 0.018 & 1.251 & 0.739 & 0.090 & -0.698 & 0.667 & 0.295 \\
\hline Trust effect & $\chi^{2}(7)$ & 49.817 & & 0.000 & 48.986 & & 0.000 & 47.820 & & 0.000 & 8.434 & & 0.296 & 32.151 & & 0.000 \\
\hline Media effect & $\chi^{2}(8)$ & 6.305 & & 0.505 & 2.801 & & 0.903 & 7.075 & & 0.421 & 3.976 & & 0.783 & 9.882 & & 0.273 \\
\hline Education eff. & $\chi^{2}(3)$ & 21.392 & & 0.000 & 13.389 & & 0.004 & 4.344 & & 0.227 & 2.891 & & 0.409 & 9.065 & & 0.028 \\
\hline
\end{tabular}


Table 3. Results of the ordered probit regression of respondents' evaluation of issues related to GMO product environmental impact (the dependent variables are measured on a 1 (totally disagree) to 5 (totally disagree) Likert scale. ( $p$-values marked in bold indicates coefficients that are statistically different from zero at $95 \%$ confidence level).

\begin{tabular}{|c|c|c|c|c|c|c|c|c|c|c|c|c|c|}
\hline & \multirow[b]{2}{*}{ Variable } & \multicolumn{3}{|c|}{$\begin{array}{l}\text { Conventional Products } \\
\text { Are Better for the } \\
\text { Environment }\end{array}$} & \multicolumn{3}{|c|}{$\begin{array}{l}\text { GMO Products Use } \\
\text { Less Natural } \\
\text { Resources }\end{array}$} & \multicolumn{3}{|c|}{$\begin{array}{c}\text { GMO Products } \\
\text { Have Less } \\
\text { Pesticide Residuals }\end{array}$} & \multicolumn{3}{|c|}{$\begin{array}{l}\text { GMO Products May } \\
\text { Help Mitigating } \\
\text { Climate Change }\end{array}$} \\
\hline & & Coef. & S. Err. & $p$-Val. & Coef. & S. Err. & $p$-Val. & Coef. & S. Err. & $p$-Val. & Coef. & S. Err. & $p$-Val. \\
\hline & GEN & -0.119 & 0.166 & 0.475 & 0.011 & 0.173 & 0.951 & 0.255 & 0.166 & 0.125 & -0.624 & 0.190 & 0.001 \\
\hline & GRAD & -0.075 & 0.282 & 0.790 & -0.349 & 0.241 & 0.148 & 0.266 & 0.281 & 0.345 & -0.850 & 0.328 & 0.010 \\
\hline & STEM & -0.021 & 0.186 & 0.911 & -0.208 & 0.181 & 0.249 & 0.247 & 0.177 & 0.162 & -0.429 & 0.174 & 0.014 \\
\hline & STEM $^{*}$ GRAD & 0.021 & 0.422 & 0.960 & 0.840 & 0.452 & 0.063 & 0.061 & 0.509 & 0.905 & 0.768 & 0.392 & 0.050 \\
\hline \multirow{8}{*}{$\begin{array}{c}t_{i p} \\
\text { variables }\end{array}$} & Farmers & 0.133 & 0.098 & 0.173 & 0.033 & 0.098 & 0.734 & -0.170 & 0.095 & 0.074 & 0.106 & 0.093 & 0.255 \\
\hline & Corporations & -0.255 & 0.099 & 0.010 & -0.105 & 0.092 & 0.255 & 0.154 & 0.098 & 0.115 & -0.287 & 0.092 & 0.002 \\
\hline & Environ. Assoc. & 0.171 & 0.091 & 0.062 & -0.246 & 0.089 & 0.006 & -0.293 & 0.092 & 0.001 & -0.013 & 0.084 & 0.879 \\
\hline & Consumer Assoc. & 0.140 & 0.111 & 0.210 & 0.197 & 0.125 & 0.116 & 0.040 & 0.121 & 0.744 & -0.018 & 0.122 & 0.886 \\
\hline & Physicians & -0.114 & 0.105 & 0.278 & -0.116 & 0.109 & 0.289 & 0.199 & 0.104 & 0.055 & -0.112 & 0.113 & 0.321 \\
\hline & Researchers & -0.141 & 0.126 & 0.263 & 0.178 & 0.111 & 0.108 & 0.200 & 0.106 & 0.060 & -0.112 & 0.118 & 0.341 \\
\hline & Friends/Relatives & 0.024 & 0.112 & 0.833 & -0.184 & 0.106 & 0.082 & -0.184 & 0.104 & 0.078 & -0.045 & 0.108 & 0.678 \\
\hline & ATIP & -0.170 & 0.204 & 0.405 & 0.239 & 0.239 & 0.316 & 0.550 & 0.222 & 0.013 & -0.520 & 0.182 & 0.004 \\
\hline \multirow{9}{*}{$\begin{array}{c}\mathrm{cm}_{\mathrm{l}} \\
\text { variables }\end{array}$} & Newspaper & -0.102 & 0.180 & 0.573 & 0.344 & 0.198 & 0.082 & 0.035 & 0.174 & 0.842 & -0.264 & 0.170 & 0.120 \\
\hline & Radio & 0.004 & 0.176 & 0.983 & 0.100 & 0.150 & 0.504 & 0.004 & 0.157 & 0.979 & 0.114 & 0.148 & 0.441 \\
\hline & TV & -0.112 & 0.153 & 0.465 & 0.146 & 0.147 & 0.321 & 0.077 & 0.156 & 0.623 & -0.156 & 0.158 & 0.324 \\
\hline & Websites & -0.248 & 0.154 & 0.106 & 0.103 & 0.171 & 0.546 & 0.075 & 0.168 & 0.653 & 0.193 & 0.161 & 0.232 \\
\hline & Social Media & -0.260 & 0.125 & 0.038 & 0.078 & 0.120 & 0.515 & 0.147 & 0.123 & 0.231 & 0.000 & 0.136 & 0.998 \\
\hline & P2P Media & -0.264 & 0.170 & 0.119 & 0.261 & 0.157 & 0.097 & 0.051 & 0.170 & 0.764 & -0.088 & 0.165 & 0.594 \\
\hline & e-Buzzword & -0.079 & 0.132 & 0.548 & -0.016 & 0.129 & 0.903 & 0.057 & 0.128 & 0.656 & -0.062 & 0.124 & 0.618 \\
\hline & $\mathrm{ACM}$ & 0.246 & 0.145 & 0.089 & -0.102 & 0.149 & 0.493 & -0.187 & 0.149 & 0.208 & 0.547 & 0.155 & 0.000 \\
\hline & constant & 1.637 & 0.667 & 0.014 & 1.453 & 0.811 & 0.073 & 0.005 & 0.693 & 0.994 & 1.938 & 0.675 & 0.004 \\
\hline Trust effect & $\operatorname{chi2}(7)$ & 26.109 & & 0.000 & 19.896 & & 0.006 & 37.070 & & 0.000 & 17.233 & & 0.016 \\
\hline Media effect & chi2(7) & 9.628 & & 0.292 & 8.879 & & 0.353 & 3.357 & & 0.910 & 8.758 & & 0.363 \\
\hline Education eff. & chi2(3) & 0.088 & & 0.993 & 3.789 & & 0.285 & 3.124 & & 0.373 & 9.257 & & 0.026 \\
\hline
\end{tabular}


Table 4. Results of the ordered probit regression of respondents' evaluation of ethical issues related to GMO products (the dependent variables are measured on a 1 (totally disagree) to 5 (totally disagree) Likert Scale. ( $p$-values marked in bold indicates coefficients that are statistically different from zero at $95 \%$ confidence level).

\begin{tabular}{|c|c|c|c|c|c|c|c|c|c|c|c|c|c|}
\hline & \multirow[b]{2}{*}{ Variable } & \multicolumn{3}{|c|}{$\begin{array}{l}\text { GMO Products may Help } \\
\text { Fighting World Hunger }\end{array}$} & \multicolumn{3}{|c|}{$\begin{array}{l}\text { GMO Products } \\
\text { Are Not Natural }\end{array}$} & \multicolumn{3}{|c|}{$\begin{array}{c}\text { GMO Products } \\
\text { Do Not Respect Life }\end{array}$} & \multicolumn{3}{|c|}{$\begin{array}{l}\text { GMO Products } \\
\text { Are for Profits Only }\end{array}$} \\
\hline & & Coef. & S. Err. & $p$-Val. & Coef. & S. Err. & $p$-Val. & Coef. & S. Err. & $p$-Val. & Coef. & S. Err. & $p$-Val. \\
\hline & GEN & 0.294 & 0.169 & 0.082 & -0.236 & 0.171 & 0.169 & -0.432 & 0.186 & 0.021 & -0.220 & 0.189 & 0.245 \\
\hline & GRAD & -0.648 & 0.271 & 0.017 & 0.103 & 0.311 & 0.741 & 0.058 & 0.301 & 0.846 & -0.466 & 0.272 & 0.086 \\
\hline & STEM & 0.201 & 0.177 & 0.256 & -0.239 & 0.202 & 0.238 & -0.446 & 0.184 & 0.015 & -0.162 & 0.180 & 0.370 \\
\hline & STEM ${ }^{*}$ GRAD & 0.359 & 0.378 & 0.342 & -0.313 & 0.438 & 0.475 & 0.300 & 0.398 & 0.451 & 0.800 & 0.394 & 0.042 \\
\hline \multirow{7}{*}{$\begin{array}{c}\text { tip } \\
\text { variables }\end{array}$} & Farmers & -0.083 & 0.109 & 0.446 & 0.055 & 0.111 & 0.623 & 0.064 & 0.098 & 0.518 & 0.216 & 0.097 & 0.026 \\
\hline & Corporations & 0.235 & 0.111 & 0.035 & -0.374 & 0.099 & 0.000 & -0.290 & 0.083 & 0.000 & -0.159 & 0.087 & 0.069 \\
\hline & Environ. Assoc. & -0.135 & 0.101 & 0.182 & 0.078 & 0.097 & 0.423 & 0.099 & 0.099 & 0.316 & 0.222 & 0.092 & 0.016 \\
\hline & Physicians & 0.104 & 0.095 & 0.270 & -0.025 & 0.105 & 0.815 & -0.056 & 0.101 & 0.583 & -0.078 & 0.100 & 0.434 \\
\hline & Researchers & 0.162 & 0.117 & 0.169 & 0.013 & 0.118 & 0.912 & -0.218 & 0.118 & 0.064 & -0.269 & 0.116 & 0.020 \\
\hline & Friends/Relatives & -0.129 & 0.112 & 0.248 & -0.006 & 0.103 & 0.951 & 0.099 & 0.103 & 0.337 & 0.189 & 0.110 & 0.087 \\
\hline & ATIP & 0.047 & 0.226 & 0.836 & 0.116 & 0.211 & 0.583 & -0.167 & 0.224 & 0.457 & -0.763 & 0.236 & 0.001 \\
\hline \multirow{8}{*}{$\begin{array}{c}c m_{l} \\
\text { variables }\end{array}$} & Newspaper & -0.137 & 0.178 & 0.440 & 0.255 & 0.165 & 0.123 & 0.026 & 0.187 & 0.887 & 0.005 & 0.177 & 0.976 \\
\hline & Radio & -0.183 & 0.157 & 0.245 & 0.145 & 0.151 & 0.334 & 0.196 & 0.169 & 0.246 & -0.103 & 0.158 & 0.515 \\
\hline & TV & 0.176 & 0.148 & 0.234 & -0.040 & 0.164 & 0.806 & 0.085 & 0.177 & 0.633 & -0.066 & 0.148 & 0.654 \\
\hline & Websites & -0.112 & 0.160 & 0.482 & 0.158 & 0.170 & 0.354 & 0.032 & 0.176 & 0.857 & -0.163 & 0.166 & 0.325 \\
\hline & Blogs & -0.184 & 0.156 & 0.239 & 0.012 & 0.174 & 0.947 & 0.124 & 0.192 & 0.520 & -0.188 & 0.170 & 0.270 \\
\hline & e-Buzzword & -0.168 & 0.120 & 0.160 & -0.042 & 0.139 & 0.762 & -0.030 & 0.139 & 0.830 & -0.147 & 0.131 & 0.261 \\
\hline & ACM & -0.085 & 0.145 & 0.558 & 0.313 & 0.133 & 0.019 & 0.283 & 0.167 & 0.090 & 0.382 & 0.155 & 0.014 \\
\hline & constant & 0.963 & 0.765 & 0.208 & 0.655 & 0.740 & 0.376 & 1.309 & 0.736 & 0.075 & 2.957 & 0.723 & 0.000 \\
\hline Trust effect & chi2(7) & 24.497 & & 0.000 & 25.611 & & 0.000 & 40.947 & & 0.000 & 51.866 & & 0.000 \\
\hline Media effect & chi2(8) & 11.999 & & 0.151 & 7.837 & & 0.450 & 3.666 & & 0.886 & 7.136 & & 0.522 \\
\hline Education effect & chi2(3) & 12.295 & & 0.006 & 3.338 & & 0.342 & 7.539 & & 0.057 & 4.401 & & 0.221 \\
\hline
\end{tabular}




\section{Discussion}

The regression results support the conclusion that educated millennials' beliefs about GMO products are not driven by scientific knowledge alone. We find statistical evidence that trust in information providers shapes respondents' beliefs. The findings confirm previous results in the literature (e.g., [6,34]). We find a significant trust effect in the evaluation of 12 claims out of 13. The most influential information providers are Environmental Associations and Corporation (affecting beliefs in eight claims each).

Our empirical investigation finds that some interested information providers are consistently associated with positive or negative beliefs about GMO products. Respondents trusting environmental associations or farmers more are more likely to totally agree with statements stressing possible risks or downsides of GMO products. Similarly, those trusting corporations more show a more positive attitude than others. This finding provides empirical support for the assumptions of theoretical models about information competition in the industry and the role of interested information providers $([11,43,44])$.

The trust effect is heterogeneous across regressions. Trust in environmental associations affects beliefs about health and environmental claims [56]. Corporation influence, instead, covers ethical issues as well. Noticeably, trust in researchers is a statistically significant variable in the evaluation of health concerns only. This finding is only partially consistent with previous literature assessing the high reputation of researchers $[49,50]$.

These results suggest that educated millennials builds their beliefs considering different information sources depending on the nature of the issue [57]. Rather than being dependent on a single information provider, educated millennials are able to combine different sources to build their evaluations. When health is considered, respondents believe that researchers are the appropriate sources for competent and unbiased information. When the questions relate to ethical issues, respondents are influenced by other information providers and researchers and scientific knowledge become almost irrelevant. Interestingly, the evaluation of environmental issues is closer to the pattern detected for ethical claims than for health ones [58] This finding partially contrasts with previous studies (such as [41]) concluding that education programs were needed in order to promote a scientific assessment of GMO products. Our analysis suggests that such programs might not affect the evaluation of ethical and environmental claims.

Our model does not provide evidence of any media effect. The tests on the joint statistical significance of the $\mathrm{cm}$ variables about the confidence in media reliability failed to reject the null hypothesis in all regressions. We conclude that, after controlling for trust, the role of media in determining educated millennials' beliefs is marginal. Media can be considered as the means information providers use to reach consumers, and have no role per se. This result contradicts previous studies reporting a media effect $([8,10,59])$ and calls for future research.

An education effect, measuring the impact of respondents' scientific knowledge, is found mainly in the regressions of health claims (except for the one about allergies). One environmental claim (about climate change mitigation) and one ethical claim (about fighting world hunger) show a statistically significant education effect as well. Similar to trust effect, impact of education on beliefs depends on the issue considered and it appears to be associated mainly with health concerns.

We did not find decisive evidence of a positive meta-attitude effect in STEM students. The coefficients of the STEM variable, when statistically significant, is consistently associated with positive beliefs about GMO products, with the exception of the claim about climate change mitigation. However, there is no consistent evidence of a decisive education effect in the evaluation of ethical claims, suggesting that STEM students have no ethical bias in favor of GMO products.

\section{Conclusions}

We investigated the factors affecting educated millennials' evaluation of credence attributes of GMO products. We found that educated millennials build their beliefs regarding health, environmental and ethical issues in GMO product consumption using a mix of scientific knowledge and trust in 
information providers. The role of the two drivers differs depending on the issue considered. Scientific knowledge is associated mainly with health claims, while trust effects are almost ubiquitous. Once trust effect is controlled for, confidence in the reliability of traditional and social media does not affect respondents' beliefs. This result contradicts previous literature.

Our results suffer from two main limitations. We focus on a very specific population segment: college students from mid-size universities in central Italy. This choice has a clear advantage of providing a population as homogenous as possible, limiting the possible bias from unobserved heterogeneity. Yet, the approach may limit the generality of results and future research is needed to confirm the results.

A second limitation is due to the use of stated beliefs in our analysis. Although we reduced possible problems by focusing on general claims (instead of stated behavior), still the use of hypothetical statements may suffer from self-representation bias. Further research might be needed in this regard, to confirm the results using different approaches (such as experiments).

The results of our analysis question few conclusions in the literature regarding the role of social media and the effectiveness of information programs. Further research in the field might focus on two main direction. The first issue is the disentangling of the trust and the media effects to confirm (or contradict) the preeminence of the former on the latter. The second direction concerns the explanation of why the role of scientific knowledge in determining beliefs depends on the nature of the issues.

Author Contributions: Conceptualization, M.A.P., C.R. and M.S.; methodology, M.A.P., C.R. and M.S.; formal analysis, C.R.; investigation, M.A.P., C.R. and M.S.; data curation, M.A.P., C.R.; writing-original draft preparation, M.A.P., C.R. and M.S.; writing-review and editing, M.A.P., C.R. and M.S.; Supervision M.A.P., C.R. and M.S. All authors have read and agreed to the published version of the manuscript

Funding: This research received no external funding.

Conflicts of Interest: The authors declare no conflict of interest.

\section{Appendix A. English Translation of the Questionnaire}

Identification of the Data Collector:

$$
\text { [...] }
$$

Privacy Statement and Data Treatment

$$
\text { [...] }
$$

Objective of the Survey:

This questionnaire contributes to a study on young consumers' perception of food products containing genetically modified products (GMO products). According to the World Health Organization, "genetically modified (GM) foods are foods derived from organisms whose genetic material (DNA) has been modified in a way that does not occur naturally, e.g., through the introduction of a gene from a different organism. The technology is often called "modern biotechnology" or "gene technology", sometimes also "recombinant DNA technology" or "genetic engineering". Currently available GM foods stem mostly from plants, but in the future foods derived from GM microorganisms or GM animals are likely to be introduced on the market. Most existing genetically modified crops have been developed to improve yield through the introduction of resistance to plant diseases or of increased tolerance of herbicides. GM foods can also allow for reductions in food prices through improved yields and reliability.

We kindly ask you to answer to the following questions about your own perception. The first part of the questionnaire collects few demographic data, the second part asks you to agree or disagree with a set of statements regarding GMO products and the third part investigates your trust in a list of information providers and media.

The survey targets college students less than 36 years old (millennials). If you are not in this group, please disregard the questionnaire. We thank you for your time and support in our research. 
I read and accept the privacy statement

Yes $\square$ No $\square$

I give my consent to data treatment

Yes $\square$ No $\square$

Part I: Background Information

Residence (NUTS2):

Gender:

Age:

Education (diploma):

Are you enrolled in a university program?
No $\square$
Yes, undergraduate $\square$
Yes, master's
Yes, other $\square$

What kind of program are you enrolled in?

STEM (Science, Technology, Engineering, Mathematics) field $\square$ Other fields $\square$

Part II: Perception of GMO Products

Table A1. Please rate how much you agree or disagree with the following statement on a five-point scale:1: Totally disagree, 2: Disagree, 3: Neither agree nor disagree, 4: Agree, 5: Totally agree.

\begin{tabular}{lllll}
\hline & 1 & 2 & 3 & 4 \\
\hline GMO products are safe \\
GMO products may cause cancer \\
GMO products may change my body cells \\
GMO products may cause allergies \\
GMO products may help preventing diseases \\
Conventional products (NO GMO) are better \\
for the environment \\
GMO products use fewer natural resources \\
(water, soil, etc.) \\
GMO products use less pesticides \\
GMO products help mitigating climate change \\
GMO products help fighting world hunger \\
GMO products are not natural \\
GMO products do not respect life \\
The only reason for producing GMO products \\
is firms' profit
\end{tabular}


Part III Assessment of Information Providers and Media

Table A2. The following groups often release information about GMO products. Please rate how much they are trustworthy on a 1-to-5 scale: 1: Totally untrustworthy, 2: Untrustworthy, 3: Neither trustworthy nor untrustworthy, 4: Trustworthy, 5: Totally trustworthy.

\begin{tabular}{llllll} 
& 1 & 2 & 3 & 4 & 5 \\
\hline Farmers & & & & & \\
Corporations & & & & & \\
Environmental associations & & & & & \\
Consumer associations & & & & & \\
Physicians & & & & \\
Researchers & & & & \\
Friends/relatives & & & & \\
Other experts & & & \\
\hline
\end{tabular}

Table A3. The following media often report news and information about GMO products. Please rate how confident you are in their reliability on a 1-to-5 scale: 1: Totally unreliable, 2: Unreliable, 3: Neither reliable nor unreliable, 4: Reliable, 5: Totally reliable.

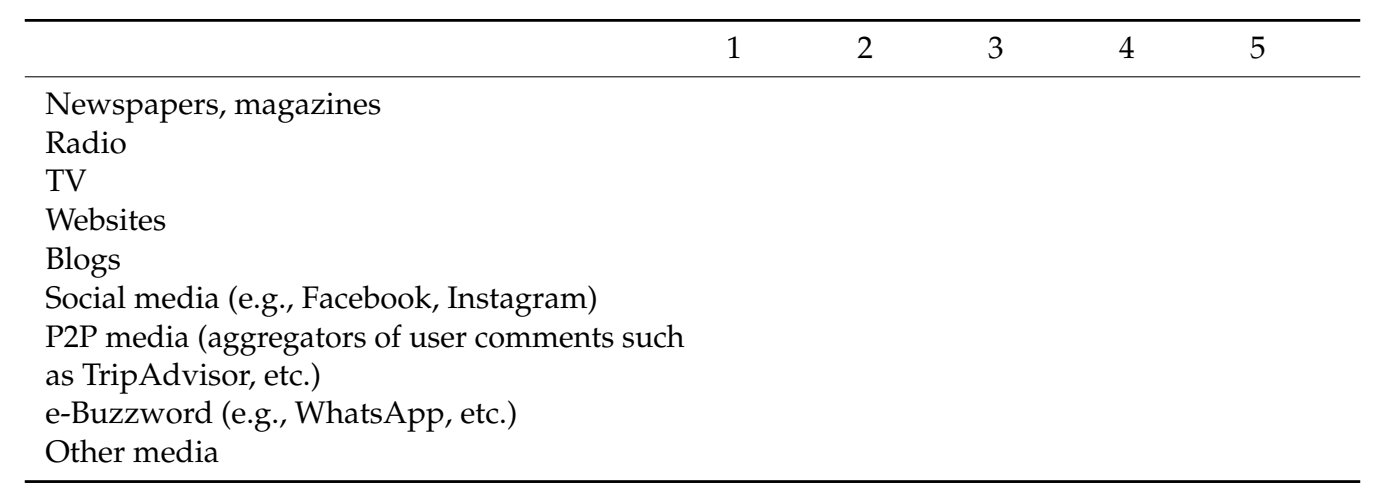

\section{References}

1. Öz, B.; Unsal, F.; Movassaghi, H. Consumer attitudes toward genetically modified food in the United States: Are Millennials different? J. Transnatl. Manag. 2017, 23, 3-21. [CrossRef]

2. Nazzaro, C.; Lerro, M.; Stanco, M.; Marotta, G. Do consumers like food product innovation? An analysis of willingness to pay for innovative food attributes. Br. Food J. 2019, 121, 1413-1427. [CrossRef]

3. Linnhoff, S.; Volovich, E.; Smith, M.; Martin, H.M. An Examination of Millennialss Attitudes Toward Genetically Modified Organism (GMO) Foods: Is it Franken-Food or Super-Food? SSRN Electron. J. 2014, 13, 371-390. [CrossRef]

4. Kajale, D.B.; Becker, T. Factors Influencing Young Consumers' Acceptance of Genetically Modified Food in India. J. Food Prod. Mark. 2014, 21, 1-21. [CrossRef]

5. Rojas-Méndez, J.I.; Ahmed, S.A.; Claro-Riethmüller, R.; Spiller, A. Acceptance of Genetically Modified Foods with Health Benefits: A Study in Germany. J. Food Prod. Mark. 2012, 18, 200-221. [CrossRef]

6. Kim, R.; Boyd, M. Japanese Consumers' Acceptance of Genetically Modified (GM) Food. J. Food Prod. Mark. 2006, 12, 45-57. [CrossRef]

7. Palmieri, N.; Simeone, M.; Russo, C.; Perito, M.A. Profiling young consumers' perceptions of GMO products: A case study on Italian undergraduate students. Int. J. Gastron. Food Sci. 2020, 21, 100224. [CrossRef]

8. Wunderlich, S.; A Gatto, K. Consumer Perception of Genetically Modified Organisms and Sources of Information. Adv. Nutr. 2015, 6, 842-851. [CrossRef]

9. Russo, C.; Simeone, M. The growing influence of social and digital media. Br. Food J. 2017, 119, $1766-1780$. [CrossRef]

10. McHughen, A. GM crops and foods. GM Crop. Food 2013, 4, 172-182. [CrossRef] 
11. Russo, C.; Tufi, E. Consumer Behavior Under Conflicting Information Provided by Interested Parties: Implications for Equilibrium in the Market for Credence Goods. Recent Pat. Food Nutr. Agric. 2016, 8, 4-8. [CrossRef] [PubMed]

12. Shew, A.M.; Danforth, D.M.; Nalley, L.L.; Nayga, R.M.; Tsiboe, F.; Dixon, B.L. New innovations in agricultural biotech: Consumer acceptance of topical RNAi in rice production. Food Control. 2017, 81, 189-195. [CrossRef]

13. Kaneko, N.; Chern, W.S. Willingness to Pay for Non-Genetically Modified Food: Evidence of Hypothetical Bias from An Auction Experiment in Japan 2004. Available online: https://ageconsearch.umn.edu/record/20305/ (accessed on 18 August 2020).

14. Bennett, A.B.; Chi-Ham, C.; Barrows, G.; Sexton, S.; Zilberman, D. Agricultural Biotechnology: Economics, Environment, Ethics, and the Future. Annu. Rev. Environ. Resour. 2013, 38, 249-279. [CrossRef]

15. Costa-Font, M.; Gil, J.M.; Traill, W.B. Consumer acceptance, valuation of and attitudes towards genetically modified food: Review and implications for food policy. Food Policy 2008, 33, 99-111. [CrossRef]

16. Frewer, L.J.; Coles, D.; Houdebine, L.-M.; Kleter, G. Attitudes towards genetically modified animals in food production. Br. Food J. 2014, 116, 1291-1313. [CrossRef]

17. Nicolia, A.; Manzo, A.; Veronesi, F.; Rosellini, D. An overview of the last 10 years of genetically engineered crop safety research. Crit. Rev. Biotechnol. 2013, 34, 77-88. [CrossRef]

18. Tagliabue, G. The necessary "GMO" denialism and scientific consensus. J. Sci. Commun. 2016, 15, Y01. [CrossRef]

19. Jackson, L.A.; Anderson, K. Why are US and EU policies toward GMOs so different? AgBioForum 2003, 6, 95-100.

20. Bäck, H.; Debus, M.; Tosun, J. Partisanship, Ministers, and Biotechnology Policy. Rev. Policy Res. 2015, 32, 556-575. [CrossRef]

21. Wesseler, J.; Kalaitzandonakes, N. Present and Future EU GMO Policy. In Palgrave Advances in Bioeconomy: Economics and Policies; Springer Science and Business Media LLC: Berlin/Heidelberg, Germany, 2019; pp. 245-256.

22. Popek, S.; Halagarda, M. Genetically modified foods: Consumer awareness, opinions and attitudes in selected EU countries. Int. J. Consum. Stud. 2017, 27, 277-332. [CrossRef]

23. Palmieri, N.; Perito, M.A.; Lupi, C. Consumer acceptance of cultured meat: Some hints from Italy. Br. Food J. 2020. [CrossRef]

24. Le Marre, K.N.; Witte, C.L.; Burkink, T.J.; Grünhagen, M.; Wells, G.J. A Second Generation of Genetically Modified Food. J. Food Prod. Mark. 2007, 13, 81-100. [CrossRef]

25. Domingo, J.L.; Bordonaba, J.G. A literature review on the safety assessment of genetically modified plants. Environ. Int. 2011, 37, 734-742. [CrossRef]

26. Nielsen, T. Consumer Buying Behavior of Genetically Modified Fries in Germany. J. Food Prod. Mark. 2013, 19, 41-53. [CrossRef]

27. Gurău, C.; Ranchhod, A. The futures of genetically-modified foods: Global threat or panacea? Futures 2016, 83, 24-36. [CrossRef]

28. Tsatsakis, A.M.; Nawaz, M.A.; Kouretas, D.; Balias, G.; Savolainen, K.; Tutelyan, V.A.; Golokhvast, K.S.; Lee, J.D.; Yang, S.-H.; Chung, G. Environmental impacts of genetically modified plants: A review. Environ. Res. 2017, 156, 818-833. [CrossRef]

29. Scott, S.E.; Inbar, Y.; Rozin, P. Evidence for Absolute Moral Opposition to Genetically Modified Food in the United States. Perspect. Psychol. Sci. 2016, 11, 315-324. [CrossRef] [PubMed]

30. Christiansen, A.T.; Andersen, M.M.; Kappel, K. Are current EU policies on GMOs justified? Transgenic Res. 2019, 28, 267-286. [CrossRef]

31. Ribeiro, T.G.; Barone, B.; Behrens, J.H. Genetically modified foods and their social representation. Food Res. Int. 2016, 84, 120-127. [CrossRef]

32. Roberts, R.J. The Nobel Laureates' Campaign Supporting GMOs. J. Innov. Knowl. 2018, 3, 61-65. [CrossRef]

33. Perito, M.A.; Di Fonzo, A.; Sansone, M.; Russo, C. Consumer acceptance of food obtained from olive by-products. Br. Food J. 2019, 122, 212-226. [CrossRef] 
34. Li, R.; Basu, A.K. Pricing Strategy for GM Food: Impact of Consumer Attitude Heterogeneity and GMO Food Labelling. Ann. Oper. Res. 2019, 291, 463-474. [CrossRef]

35. Zhang, C.; Wohlhueter, R.; Zhang, H. Genetically modified foods: A critical review of their promise and problems. Food Sci. Hum. Wellness 2016, 5, 116-123. [CrossRef]

36. Hellsten, I. Focus on Metaphors: The Case of "Frankenfood" on the Web. J. Comput. Commun. 2006, 8, 841. [CrossRef]

37. Kniazeva, M. Marketing “Frankenfood”. J. Food Prod. Mark. 2006, 11, 21-39. [CrossRef]

38. Bardin, B.; Perrissol, S.; Facca, L.; Smeding, A. From risk perception to information selection ... And not the other way round: Selective exposure mechanisms in the field of genetically modified organisms. Food Qual. Prefer. 2017, 58, 10-17. [CrossRef]

39. McComas, K.A.; Besley, J.C.; Steinhardt, J. Factors influencing U.S. consumer support for genetic modification to prevent crop disease. Appetite 2014, 78, 8-14. [CrossRef]

40. Mielby, H.; Sandøe, P.; Lassen, J. The role of scientific knowledge in shaping public attitudes to GM technologies. Public Underst. Sci. 2012, 22, 155-168. [CrossRef]

41. Kim, N.H.; Hwang, J.Y.; Lee, H.G.; Song, M.K.; Kang, Y.S.; Rhee, M.S. Strategic approaches to communicating with food consumers about genetically modified food. Food Control. 2018, 92, 523-531. [CrossRef]

42. Park, H.S.; Lee, S.Y. Genetically Engineered Food Labels, Information or Warning to Consumers? J. Food Prod. Mark. 2003, 9, 49-62. [CrossRef]

43. Kamotani, S.; Hooker, N.; Smith, S.; Lee, K. Consumer Acceptance of Ozone-Treated Whole Shell Eggs. J. Food Sci. 2010, 75, S103-S107. [CrossRef] [PubMed]

44. Lusk, J.L.; Roosen, J.; Bieberstein, A. Consumer Acceptance of New Food Technologies: Causes and Roots of Controversies. Annu. Rev. Resour. Econ. 2014, 6, 381-405. [CrossRef]

45. Marette, S.; Roosen, J. Bans and labels with controversial food technologies. In The Oxford Handbook of the Economics of Food Consumption and Policy; Roosen, J., Lusk, J.L., Shogren, J.F., Eds.; Oxford University Press: Oxford, UK, 2011; pp. 499-519.

46. Lerro, M.; Raimondo, M.; Stanco, M.; Nazzaro, C.; Marotta, G. Cause Related Marketing among Millennial Consumers: The Role of Trust and Loyalty in the Food Industry. Sustainability 2019, 11, 535. [CrossRef]

47. Benson, T.; Lavelle, F.; Spence, M.; Elliott, C.T.; Dean, M. The development and validation of a toolkit to measure consumer trust in food. Food Control. 2020, 110, 106988. [CrossRef]

48. Coderoni, S.; Perito, M.A. Sustainable consumption in the circular economy. An analysis of consumers' purchase intentions for waste-to-value food. J. Clean. Prod. 2020, 252, 119870. [CrossRef]

49. Dean, M.; Shepherd, R. Effects of information from sources in conflict and in consensus on perceptions of genetically modified food. Food Qual. Prefer. 2007, 18, 460-469. [CrossRef]

50. Lang, J.T. Elements of public trust in the American food system: Experts, organizations, and genetically modified food. Food Policy 2013, 41, 145-154. [CrossRef]

51. McInerney, C.; Bird, N.; Nucci, M. The Flow of Scientific Knowledge from Lab to the Lay Public. Sci. Commun. 2004, 26, 44-74. [CrossRef]

52. De Steur, H.; Liqun, G.; Van Der Straeten, D.; Lambert, W.; Gellynck, X. The Potential Market for GM Rice with Health Benefits in a Chinese High-Risk Region. J. Food Prod. Mark. 2014, 21, 231-243. [CrossRef]

53. Lancaster, K.T. A New Approach to Consumer Theory. J. Political Econ. 1966, 74, 132-157. [CrossRef]

54. Maddala, G.S. Limited-Dependent and Qualitative Variables in Econometrics; Cambridge University Press (CUP): Cambridge, UK, 1983.

55. Costa-Font, M.; Gil, J.M. Meta-attitudes and the local formation of consumer judgments towards genetically modified food. Br. Food J. 2012, 114, 1463-1485. [CrossRef]

56. Scarpato, D.; Rotondo, G.; Simeone, M.; Gómez, A.; Gutiérrez, P. How can food companies attract the consumer concerned about food safety? A logit model analysis in Spain. Br. Food J. 2017, 119, 1705-1717. [CrossRef]

57. Perito, M.A.; Coderoni, S.; Russo, C. Consumer Attitudes towards Local and Organic Food with Upcycled Ingredients: An Italian Case Study for Olive Leaves. Foods 2020, 9, 1325. [CrossRef] [PubMed] 
58. Di Talia, E.; Simeone, M.; Scarpato, D. Consumer behaviour types in household food waste. J. Clean. Prod. 2019, 214, 166-172. [CrossRef]

59. Simeone, M.; Scarpato, D. Sustainable consumption: How does social media affect food choices? J. Clean. Prod. 2020, 124036. [CrossRef]

Publisher's Note: MDPI stays neutral with regard to jurisdictional claims in published maps and institutional affiliations.

(C) 2020 by the authors. Licensee MDPI, Basel, Switzerland. This article is an open access article distributed under the terms and conditions of the Creative Commons Attribution (CC BY) license (http://creativecommons.org/licenses/by/4.0/). 